\title{
8 Conclusion and Implications
}

\author{
Prospects for popular resistance in a post-revolutionary \\ Egypt
}

\begin{abstract}
This concluding chapter discusses the findings of the previous chapters critically in light of ongoing theoretical debates on the power of nationalism, the role of affect and emotions, the imprint of violent events such as Rabaa on the collective memory of a people, and the resurgence of autocracy in the Middle East. It highlights the merits of a disaggregated and culture-sensitive interactionist approach to the study of protest and repression, reflects on the implications and limitations of this study, and offers points of contact for further comparative research. Finally, the concluding chapter assesses the prospects for popular resistance in contemporary Egypt.
\end{abstract}

Keywords: autocracy, discursive arenas, protest-repression dynamics, strategic interactionism, contentious politics

As Lisa Wedeen (1999) maintains in her political ethnography of Syrian authoritarianism, politics is "not merely about material interest but also about contests over the symbolic world, over the management and appropriation of meaning" (p. 30). The 2011 popular uprising effectively illustrated this process, demonstrating how the proliferation of a new vision of the Egyptian people was triggered by a dislocation of the discourse that had sustained Mubarak's rule. His claim to govern in the name, for the sake, and on behalf of the people had been undermined by years of negligence, unequal economic development, and barred access of Egyptian civil society to meaningful socio-economic and political participation. The performative disruption of this illusion on January 25, 2011, brought this latent crisis to the fore (Chalcraft, 2014, p. 175). The participants in the first mass protest were instrumental in physically breaking through the barrier of fear in that they

Grimm, Jannis Julien, Contested Legitimacies: Repression and Revolt in Post-Revolutionary Egypt. Amsterdam: Amsterdam University Press 2022 DOI: $10.5117 / 9789463722650$ _CHO8 
overpowered the deployed riot police and claimed ownership over public space by taking Tahrir Square. Moreover, through their protest, they also expanded the horizon of possibilities in terms of what was arguable with a view to the country's future. This opening discursive space - through the disruption and appropriation of meaning - impacted the potentials for subsequent mobilization and coalition building and culminated in the breakdown of the alliance of players that had ruled Egypt for several decades.

Countless new political projects originated from the dislocation of the hegemonic order: with the demise of Mubarak's regime, particularly the notion of "popular legitimacy" became a floating signifier that different factions wove into different discourses in their attempt to garner support for their political projects and shape the political transformation in the aftermath of the uprising. Their contending strategies, political competition, and ideological fragmentation have been described in several recapitulations of Egypt's democratic transition and the reasons for its failure (e.g., Abdelrahman, 2015; El-Sharnouby, 2018a; Marfleet, 2016; Rennick, 2015; Sika, 2017). Albeit rooted in different epistemological and theoretical paradigms, what these works have in common is that they underscore how the disruptions created by the Tahrir uprising left a vacuum in the political arena that different (revolutionary and reactionary) players attempted to fill with their projects. But rather than creating a shared vision for the revolutionary moment, these projects fell short of proposing a unifying "affirmative idea" (see Herrera \& El-Sharnouby, 2018) for a new participatory order. Instead, as Pratt (2015) argues, the January 25 Revolution marked only the beginning of "the next phase" in the ongoing efforts of civil society to resist authoritarianism.

This book has picked up where prior works left off and focused on this next phase and the events after the heavily studied Arab Spring. However, it has attempted to avoid reproducing the structuralist bias of earlier works, as well as the simplifying diagnosis of Egypt's transition as a return to square one which followed from normative assumptions of change as a gradual process towards democracy and evoked false connotations of stagnation and a halted political process. Instead, the eight chapters of this book portray the country's trajectory as the highly contingent outcome of dynamic interactions. By adopting a cultural interactionist perspective, politics in Egypt after the coup are conceived of as an ongoing struggle between various individual and compound players over the sources, meaning, and consequences of political legitimacy. This struggle manifested in a sequence of protest and repression events, of which some had a transformative impact on the composition of the political arena. And it took place in a discursive 
arena, too, where players interacted by wielding competing narratives about the unfolding events as discursive weapons against each other.

This book showed how these two "arenas" (Jasper \& Volpi, 2018, p. 15ff.), that is, street politics and the politics of signification, interrelated and informed the trajectory of the country's post-revolutionary order. Its results confirm those of Alberto Melucci (1996) who famously maintained that the ability of today's social movements to generate a serious challenge to prevailing structures of domination hinges on their symbolic capacity to subvert, reverse and redefine social meaning. Thereby they can demonstrate the arbitrariness of power and its manifold justifications. In a similar vein, I have argued throughout this book that in the case of post-revolutionary Egypt, discursive struggles determined the conditions of possibility for contentious interactions on the ground and thus the political opportunities for resistance or repression.

The discourses articulated in relation to contentious events crucially accounted for the observed variances in the (re)actions of the main contenders vis-à-vis each other. They conditioned which social movements formed coalitions, how authorities encountered mobilization, and how the broader public took in and evaluated the performances of the main political contenders. Depending on which rival interpretation about contentious events prevailed and affected people's hearts and minds, contentious interaction triggered a backlash, created opportunities for protest, or facilitated repression.

Particularly, the challenges posed by Tamarod and the Popular Campaign to Protect the Land (PCPL) to the rules of President Mursi and President Al-Sisi, respectively, testify to the power of discursive contestation from below. They evidence that, at times, "it is enough to structure reality using different words for the power monopoly over reality to crumble" (Melucci, 1996, p. 358). Over the course of the investigation period, the mismatch between how incumbents acted and what they claimed to stand for - and players articulating this disjuncture - caused the fall of one regime, triggered the emergence of another, and planted new seeds of resistance in the current order.

\section{Autocratic Restoration through the Lenses of Contentious Politics}

Considering these findings, this book makes several contributions to the body of research on contentious politics. First and foremost, it produces a new historical narrative about the exceptional and "eventful times" (Della Porta, 2017, p. 12) of the run-up, unfolding, and aftermath of the military 
coup. Egypt's post-revolutionary history is narrated as a sequence of several contentious episodes that were each structured by a series of transformative events. Their impact on the dynamics of contention, and consequently on the country's overall political trajectory - rather than clear-cut - was manifold, often ambiguous, and volatile, but always highly dependent on the outcome of the discursive battles fought over their interpretation.

This book starts by showing that the popular-backed military intervention against President Mursi, similarly to the 2011 uprising (see Khosrokhavar, 2018), represented a constitutive event that triggered a range of new political subjectivation processes, both in the Islamist spectrum and within the coalition of contenders who had joined forces to depose Mursi through their protest campaign. As a transformative event, the military coup of July 3, 2013, broke the political stalemate that had crippled Egyptian politics throughout the first half of the year. It reshuffled the cards and provided the leading political contenders with an opportunity to redefine both the boundaries of their collective identities and their stated goals for the country's political future. The coup effectively dislocated the precarious legitimacy discourse of the Mursi administration that had sustained the status quo, throwing it into open competition with the alternative political project that had been articulated in the frame of the June 30, 2013 protest.

As described in the third chapter, the president's standing had eroded throughout his first year in office. Above all, Mursi's insistence on his constitutional legitimacy proved to be a double-edged sword. First, the quiet entente between the SCAF and the Brotherhood, which had enabled Mursi's ascension to power, had tarnished his revolutionary credentials. Then, an exclusive constitutional drafting process cemented the image that the president and his Islamist base attempted to monopolize their grip on power. Lastly, a constitutional declaration that placed the executive beyond judiciary supervision also undermined his claim to constitutionality. The performative disruption of the hegemonic order on June 30 brought this latent crisis to the fore, demonstrating how the Mursi administration had never really managed to establish hegemony for its political project in Egypt's post-revolutionary public. In this context, the Tamarod campaign became the roof for a counter-hegemonic block that successfully bundled and mobilized the widespread grievances against Mursi.

As an event that could not be signified in the ruling discourse - primed on legitimizing Mursi's rule - the second popular uprising in Egypt within two years represented a transformative event that not only dislocated the incumbent regime's claim to legitimacy but also set in motion another military intervention that culminated in the deposition of Mursi on 
July 3, 2013. This "coup-volution" (Hamada, 2014, p. 37), however, did not result in the replacement of one precarious hegemony - that of the Mursi administration and its supporting Islamist base - by another. Rather, as my discussion of the post-coup dynamics in Chapter 4 shows, the coup dichotomized the public by delimiting the frontier between two opposing political projects. Their battle for hegemony dominated and polarized Egyptian society during the rest of the investigation period. This new societal conflict cut across the formerly salient division between the people and the regime by pitting an alliance of civic and state forces that supported Mursi's ouster, including representatives of the army, political parties, social movements, and state ministries, against another equally variegated coalition of anti-coup forces.

In this contest, both sides derived their legitimacy from competing conceptions of democracy, legality, and the country's revolutionary heritage; both sides claimed to speak for the people; and both sides engaged in vicious vilification of their respective other, depicting it "as an existential threat, yet paradoxically also as a minuscule fringe side-lined by their own clear majority" (Mogahed, 2013). After the massacre of Rabaa al-Adawiya, covered in Chapter 5 , the social polarization between these projects reached a fever pitch, "people didn't just hold different opinions about the same reality - they held different realities" (Mogahed, 2013). These different realities found their articulation in opposing discourses about the contentious dynamics that unfolded in the streets and, as my argument goes, set the conditions for the ensuing modes of conflict.

On the one hand, a coalition of mostly Islamist forces kept the deposed president's discourse alive. The myth of a "National Alliance" for the restoration of legitimacy effectively became the surface of inscription of a variety of political demands that found their expression in the most significant sequence of collective actions since the 2011 uprising. Within the frame of this Anti-Coup campaign, the central signifier of resistance in the name of legitimacy provided the principal reference point for protesters' collective identity. It also limited their radicalization in reaction to state repression, illustrating the conditioning impact of discourses on action repertoires: The strong intertwining of Anti-Coup conceptions of legitimacy with notions of nonviolent resistance prevented the Islamist protest coalition from turning to violence as an action strategy. Instead, adaptive decentralization and diversification ensured the movement's survival despite severe repression.

A question yet to be answered is how sustainable this survival mechanism was in the long term. Jillian Schwedler (2018, p. 72) noted that often the significance of innovations is only recognizable with time when routine 
practices come into sharp relief. In this sense, it remains to be seen whether the described short-term tactical substitution processes that made the AntiCoup campaign resilient against state repression have indeed established long-term path dependencies, for instance, for the Muslim Brotherhood as a group. Of equal concern remains the question of violence. In the immediate post-coup context studied in this book, the interim authority's deadly violence rather confirmed the protesters' moral superiority and strengthened their internal cohesion. But extending the analysis to a longer period might challenge the weak convergence of repression and protester violence observed in this book.

At the same time, the failure of the Anti-Coup Alliance to modify or extend its legitimacy discourse in an inspiring way also forestalled the creation of coalitions beyond the ideologically aligned opposition spectrum - it also precluded popular solidarity when civilian protesters were targeted in the massacres of Rabaa al-Adawiya and Al-Nahda. Not realizing that its discourse, by association with the former president's rhetoric, was perceived by most Egyptians as a hollow shell and a smokescreen for the Muslim Brotherhood's will to power, the NASL's insistence on constitutional, democratic, and revolutionary legitimacy only deepened the divide between the pro and the anti-coup camps.

On the other side of this divide, as I have argued, the events of July 3, 2013, also marked a point of no return. After all, the interim regime that assumed control over the country after Mursi's arrest needed to counter the Muslim Brotherhood's claim to power and the Anti-Coup Alliance's attempt to establish hegemony for its understanding of legitimacy. The interim regime, therefore, refuted these forces by promoting an alternative discourse primed on nationalism and the state's ability to protect the Egyptian people from external and internal threats. Within the frame of this discourse, the army's intervention against the acting president and its repression of the Anti-Coup protests was articulated as a realization of the popular will - and thus the origin of all political legitimacy. The army was thereby portrayed as the ultimate guardian of Egyptian democracy and rehabilitated as a political actor. On this side of the political divide, as within the NASL, the propagated official narrative set the conditions of possibility for how authorities acted vis-à-vis their opponents: as a consequence of the state's securitizing logic, all bottom-up challengers to the post-coup order were framed as potential threats to the nation. Brutal state repression, including several massacres, was signified as a necessary evil to restore national security. Especially after the liminal event of Rabaa, the crackdown against protesters was articulated as an undesired but reasonable policy to confront extremist threats. 
In the end, the discursive struggle for interpretive authority over social reality polarized public opinion so strongly that it became impossible for the main contenders - the supporters of the deposed president and those of the new transitional regime - to approach their antagonists or any other political players without losing face. Furthermore, in the bifurcated political arena, all other interpretations of the contentious dynamics in Egypt were unable to gain traction. Within the context of growing fears and perceptions of insecurity in the population - owing to the everyday violence on the streets - even formerly nonpartisan players were forced to take sides. Alternative political projects for the country's political future were thereby excluded from the horizon of possibilities. As discussed in Chapter 6, the emergence of a new autocratic order can thus be considered a by-product of this polarizing conflict over discursive hegemony.

To sum up, I contend that the authoritarian restoration under the auspices of General Al-Sisi should not be viewed as the result of the deep state's machinations. Instead, it was the outcome of an iterative process of discursive labor by different players, who strategically responded to unfolding events, starting with the legitimacy crisis of the Mursi administration. In other words, the emergence of a new ruling coalition whose discourse stresses national defense and the fight against terrorism, rather than self-determination and civilian rule, was highly contingent on the eventful interaction dynamics described in this book. Their outcome was hardly predetermined. Instead, each event altered the "constellation of possibilities in the future" (Alimi \& Meyer, 2011, p. 477).

In hindsight, it can be argued that the struggle between coup and AntiCoup was conclusively decided in favor of the former. However, contrary to Egypt's delusive self-portrayal as an "anchor of stability in the region,"1 the new regime may not be as stable as it seems. Thus far, nationalist and securitizing discourses have mostly been understood as tools to co-opt popular pressure for reform into a state-centric model of governance (e.g., Amar, 2013; Brand, 2014). The potential of these discourses to serve as a magnet for contentious coalition building has been investigated only scarcely. But as Chapter 7 highlights there is nothing deterministic about nationalist ideology. It may support projects of domination, but also a "politics of emboldening in the face of institutional constraints" (Beissinger, 2002, p. 38). The case study of the Tiran and Sanafir Island protests exemplifies how activists may harness the emotional dimensions of established nationalist

1 See remarks Abdel Fattah Al-Sisi at the 71st session of the United Nations General Assembly on September 20, 2016 at https://gadebate.un.org/en/71/egypt. 
political discourse for mobilization and contentious alliance building. In this case, a controversial border demarcation agreement became the tipping point event that could not be symbolized in the nationalist discourse sustaining Al-Sisi's rule, thereby destabilizing it and creating opportunities for resistance. While failing to effect systemic change, the Egypt is not for sale!-campaign seriously challenged the post-coup regime's interpretational sovereignty. By undermining and subverting the Al-Sisi administration's image, the campaign effectively forced it into a discursive struggle over the meaning of political legitimacy and the appropriate modes of governance.

In this struggle, which is still ongoing, contentious players no longer attack the system and practices of authoritarian rule through frontal assaults, such as mass demonstrations, blockades, or strikes. Instead, they wage a discoursive war against and within the ideological complex that underpins and sustains Al-Sisi's rule. In this respect, the character of the resistance against Al-Sisi's dictatorship has assumed a form and shape that is faintly reminiscent of the decade-long opposition against the Husni Mubarak regime before the Arab Spring. At the same time, resistance, today, resembles that in the immediate aftermath of the 2011 uprisings. Described by Pratt (2015) as a war of position by civil society against military rule, its spirit is encapsulated in the phrase, "al-thawra mustamirra - the revolution continues" (p. 47).

\section{From a Relational to an Interactionist Perspective on Protest and Repression}

In addition to its historiographic value, this book highlights the opportunities for theoretical advancement offered by cultural interactionist studies of contentious politics. Approaches that are attuned to the interaction processes of key political players not only provide detailed insights into the mutual adaptation processes that take place between protesters and their counterparts in situations of contention. They also allow conceptualizing social relations - for instance, between state institutions, such as the military, and protest movements, such as the Anti-Coup coalition - as dynamic networks that are not static or predetermined but reproduced and modified through the interactions of responsive individual and compound players.

This perspective emphasizes the role of agency, leaving room for investigating the "historical contingency" of the social fabric (Jasper, 2019, p. 132), rather than taking the antagonisms, alliances, or competition between certain actors for granted as consequences of their structural disposition. Furthermore, it helps to identify and to give focus to the contestation 
processes that occur below the threshold of uprisings, which are crucial for broader social transformation but often overshadowed by episodes of mass protest that monopolize scholarly attention. Charles Kurzman (2018) warned that:

Social scientists who privilege the mass scale may dismiss small-scale disruptions as statistical noise in the signal, but for the people living through these periods of unrest, they may be the signal itself. These small-scale perturbations can come to define the historic moment. They may be the iconic feature that people latch on to as they work out which institutions are finished and which ones remain intact. (p. 19o)

Particularly in contexts of authoritarian closure, small-scale mobilizations can signal rifts in the status quo and foreshadow more sweeping change. As Vince Boudreau (2005) noted: "Challenges [posed by protests to elites] are not intense objectively, but in their relationship to capacities possessed by states" (p. 53). This point is exemplified by the case of the PCPL: As described in Chapter 5 , it required no mass uprising to expose the hollow nationalist rhetoric of the dominant regime players. Albeit small in scale, the protests were highly symbolic in that the protesters gathered in the same streets they had occupied during the 2011 uprising to defend the two Red Sea islands. Event catalogs provide a useful heuristic device to detect such small-scale disruptions by disaggregating social movements into sequences and cascades of individual events. Even within the relatively short timeframe covered in this book, the analysis of contentious interactions during these events, along with the communications of political contenders about these events, reveal a number of situational linkages that would have remained obscure to analysts were they to rely uniquely on aggregate data.

For instance, the trajectory of the Anti-Coup campaign suggests that state violence may not necessarily be the most effective tool to control social players. Rather than successfully suppressing contenders, state violence triggered mechanisms of adaptation in the Anti-Coup movement that ensured its resilience; it even produced backlash effects as evidenced in mobilization rates. The results of this disaggregated analysis caution against misinterpreting strategic substitution as behavioral reduction. As I show in this book, the perceived "defeat" of the Anti-Coup Alliance was more a consequence of its failure to detach itself from a problematic and partisan conception of legitimacy that reinforced the antagonism between the protest movement and the public, rather than enabling a broader coalition of contenders. 
The resulting analysis presented in this book needs to be interpreted with caution, however, given that the data allow for some ambivalence. Above all, they do not lend themselves to a general empirical argument. Overall, I find that over the lifespan of a movement the interactional effects of protest performances and repression on contenders, rather than clear-cut, tend to be inconsistent and punctual. Also, in empirical reality, there is usually no clear-cut dichotomy between dissenters and incumbents, such as the one investigated in this book. The binary between state and street is an elusive construct that serves simplification but does not account for the variety of players' motives.

Bearing these caveats in mind, it seems fair to state that the methodological dualism of this study does, nevertheless, reflect the central antagonism in post-coup Egypt. The June 30 uprising boosted political polarization and effectively split Egyptian society in two. In this context, most political forces uncritically welcomed the state-led crackdown on the NASL and the return of the generals to the political stage. Others felt compelled to side with the interim authorities despite their criticism of the state violence, lest they risked victimization themselves (Hamzawy \& Dunne, 2017). Few non-aligned forces, such as the Bread and Freedom Party or the moderate Islamic Strong Egypt Party of former Brotherhood Guidance Bureau member Abdel Moneim Aboul Foutuh, attempted to resist the political binary and establish themselves as a third way between the army and the Brotherhood. But they were too weak to articulate and promote their alternative visions of popular legitimacy and a post-coup order. Their voices have thus not been explored with the same level of detail as those of the leading contenders.

While outside the scope of this book, it remains worthwhile to explore these "silences" in future research. Such an investigation would not only contribute to a more nuanced picture of the dynamics that caused Mursi's fall and Al-Sisi's rise to power. In light of the autocratic restoration in Egypt and the bleak prospects for national reconciliation, returning to these early attempts to resist securitization and to offer an alternative to the two hegemonic projects portrayed in this book might also produce a new positive vision for the country and harbor the potential for resistance to the authoritarian status quo.

Related to this unexplored external multiplicity of voices, is the understudied internal variety of the compound players covered in this book. As Jasper and Volpi (2018) argued, the unity attributed to players in the reconstruction of event history is but a necessary analytical device to cope with the otherwise impalpable "multiplicity in rapidly evolving political situations" (p. 16). Talking about Tamarod, the Anti-Coup Alliance, the 
Brotherhood, or the Popular Campaign to Protect the Land may create an impression of these groups as unitary actors. But, in truth, coalitions of contenders constantly shift, expand and contract, dissolve and reassemble. These interaction processes are hinted at, for instance, when describing the changes in the composition of the NASL after the arrest of its leadership. But they harbor much more potential for further investigation. The NASL's internal rifts over violence are a case in point: In the months after the events covered in this book, radicalization at the movement's grassroots level jeopardized reconciliation in Egypt as much as the regime's crackdown.

The same is true when discussing actors such as regimes, states, and authorities, for instance. These are placeholder terms that blend over internal disagreements and power struggles experienced by these actors, and obscure the fact that the internal composition of those "on the other side" of the contentious struggle also constantly alternates (see Duyvendak \& Jasper, 2015). Such alternations often result from these actors' internal interactions and of those with other players, for instance when interim vice-president Baradei resigned in response to the state violence against the Rabaa protesters. I have endeavored to account for this fluid nature of social players by making the contingent character of cross-movement alliances the center of several sections of this book. But actually, most of the protagonists of this book could be analyzed as arenas themselves, where individual movement or regime components - down to the level of individual actors - interoperate and compete for authority over the aims, motifs, identity, and actions of the movement or the state.

The deficits as regards accounting for this multiplicity are engrained in the research aims and the methodology of this book. The act of reconstruction involved in the coding of events implies a range of simplifications that limit the ability to capture the multiplicity of protesting actors. As we face the task of determining whether and how actions converge into a single historical event, we also face the task of limiting it to the acts performed, for instance, on one day, by one group of people, in one space, or against one common target (see Wagner-Pacifici, 2010, p. 1352). This should, however, not prevent further engagement with and refinement of the proposed research design. On the contrary, future projects could attempt to develop this approach further to include an analysis of voices from within compound actors. This could be undertaken, for instance, by extending discourse analyses from official statements and joint movement positions to the examination of internal discussions - on social media or in group meetings - among the members of specific alliances; or by mapping the broader discursive context constituted by reporting and the mediated articulations of public figures 
and other political players, to assess whether it supports or undermines the principal contenders during a protest cycle.

Alternatively, subsequent studies could explore a comparative angle. The Turkish case, where an authoritarian contraction has prompted many observers to caution against a repetition of the "Egyptian model," is just one of many examples that lend themselves to such scrutiny. Comparativists have tended to view the military coups in both countries as a factor that set them apart - the coup successfully toppled a government in Egypt, while it failed to do so in Turkey. But thinking of coups as disruptive events that caused a reconfiguration of decision-making in both countries, similarities between the Egyptian and the Turkish case become apparent (see Grimm, 2017). The challenge of such investigations will be to avoid falling back to correlating a few structural variables and to develop ways to compare and contrast different sequences of micro-interactions across cases, without reducing their complex settings for the sake of horizontal comparability (see Jasper, 2019; Weipert-Fenner, 2021).

I am unable to follow these threads here because this book engages with a single case in-depth and only allows for longitudinal comparison across the discussed episodes. Nevertheless, its results seem to support the claim that a relational and bottom-up perspective - one that "acknowledges emotions along with other meanings and institutional context" (Jasper, 2018, p. 12) - may provide a more nuanced picture of the highly situational dynamics during cycles of contention. Most importantly, a picture that accounts for contenders' agency. As Jasper and Volpi (2018) noted: "Although we may focus on one player, the approach discourages us from reducing the other players to the status of structures or a static environment" (p. 16). Rather than seeking an overarching causal argument or refining threshold models for backlash, scholars investigating the mobilization-repression-nexus ought to direct their attention to interactive explanations that account equally for the material arena of contention - including protest spaces and tactics and the character of policing - and the interpretive arena where players attribute meaning to the unfolding events.

\section{Conceptualizing the Discursive Arena of Contentious Politics}

By placing attention on the link between contested discourses and contentious politics, this book demonstrates how strategic interactionist frameworks, such as the players and arenas approach developed by Jasper and Duyvendak (2015), can benefit from integration with discourse 
theory. Exploring the question "who acted how towards whom," but also how players experience these interactions emotionally, interpret them cognitively, and articulate them strategically in contending discourses can prove fruitful in reconciling the ambiguous findings that have pervaded the study of the effects of repression on social movements for decades. By systematically linking the discursive to the material in an analytical framework informed by both, post-foundationalist theories of discourse analysis and the more dynamic and agent-centric cultural interactionist perspectives on contentious politics, I have proposed a novel approach that provides a more complete picture of the dynamics of contention under conditions of authoritarianism - one that allows us to illustrate the "variety of exchanges and influences" (Jasper, 2019, p. 132) that occur through players' interactions, including the volatility of their goals and convictions, as well as their changing sympathies and enmities.

This approach complements existing strategic-interactionist perspectives in social movement studies by adding a discursive layer to them. To some degree, however, it also challenges these perspectives by highlighting the structuring effect of discursive formations on social interaction. Crucially, Jasper $(2015 \mathrm{~b})$ and his collaborators underscored the flexibility of social arenas, stressing that players and arenas were "always emerging, changing and recombining" (p. 13). With this rigorous abandonment of structure, however, they somewhat dismissed the potentially lasting and stable impact that norms and values, culturally mediated historical experiences and collective identities, and carefully forged self-images and antagonisms can have on actors' behaviors. Discursive hegemonies often reflect these rather stable social relations, thus determining the boundaries of political players as much as their arenas of engagement. As this book also shows, they can thereby indirectly structure, and thus condition, social interaction, by shaping players' expectations, their perception of opportunities for action, and their evaluation of the rules and parameters of the political arena.

Guy Accornero made a similar argument in his contribution to the " $\mathrm{Au}$ thors Meet Critics"-symposium about the players-arenas approach. There he argued that "identities, strategies, and goals do not completely emerge through the interactions among players, they are also the result of the specific background of each of them" (Accornero in McGarry et al., 2016, p. 638; see also Duyvendak \& Fillieule, 2015; Polletta \& Kretschmer, 2015). Through discourses that articulate these specific backgrounds as reference points for the collective identities and antagonisms, "these histories are pertinent in the present" (Duyvendak and Jasper, in McGarry et al., 2016, p. 639). 
The identities that are constituted through players' discourses, ultimately, define how they can experience and feel about unfolding events. They delimit their horizon of possibilities in terms of what is thinkable, arguable, and doable. Therefore, to a degree, the approach proposed in this book pushes the boundaries of the players-arenas perspective by highlighting how the discursive arena and its parameters represent a superordinate arena of struggle that regulates players' room for maneuver in other social spaces. Sometimes it enables, sometimes it restrains contentious interactions. There is little that players can do to overcome the conditioning effect of the discursive arena but engage in a proactive politics of signification to change its parameters. Discourses reflect the rules of the political game. If these rules are devised to keep movements from the playing field, resistance must start by challenging these discourses. Narratives that successfully challenge hegemonic discourses by creating new social spaces for action can thus open up entirely new arenas of contentious politics, even more effectively than other forms of mobilization (see Siméant-Germanos, 2021, p. 142ff.).

By emphasizing the transformative potential of discursive struggles on the parameters of contentious arenas, the approach I propose also goes beyond the debate on what Stefania Vicari (2015) has termed the "interpretative dimension of transformative events." In a recent intervention, Della Porta (2018) argued that eventful protests can trigger critical junctures and thereby produce abrupt changes that develop contingently and become path-dependent. In this book, I argue that discourse represents the missing link between such junctures and their impact on the trajectories of protest as transformative events. As the case of Rabaa and the disclosure of the Tiran and Sanafir deal show, critical junctures such as a coup, a massacre, or blatant foreign policy decisions constitute moments of politicking. When taken for granted assumptions about the social come into question and the horizon of possibilities for the emergence and promotion of new meanings expands, whereby "old lines of thought are disrupted, older constellations displaced, and elements, old and new, are regrouped around a different set of premises and themes" (Hall, 1980, p. 33). Precisely, the power of such moments of rupture and crisis lies not in their concreteness and the clarity of their meaning, but their interpretive malleability. This is why they represent windows of opportunity for players to develop alternatives to the status quo.

This productive dimension of critical junctures is captured in Laclau and Mouffe's concept of dislocation. Engendered by a mismatch of unfolding events on the ground and the way these events are articulated, dislocation creates ambiguity. This ambiguity opens up the possibility for multiple meanings to be inscribed and thus for processes of contestation, by new 
political players or by existing ones, that are propelled into action by the emotional and cognitive dynamics of critical junctures.

Pulling the two theoretical threads together, I have thus argued that movements can profit from the dislocations created by transformative events as symbolic resources for resistance. Both the June 30-uprising and the tale of two insignificant Red Sea islands demonstrate that blatant gaps between discourses and government policies can backfire on their agents in the same ways as severe repression and outrageous police violence sometimes do. When critical junctures render it apparent that authorities do not walk their talk, social players are provided with an opportunity to subvert the discourse that sustains the status quo and gives rules and shape to the political arena. Often, the failure of dominant players to sensibly respond to grievances allows others to articulate solidarity and to forge a common oppositional identity based on shared dissatisfaction with the status quo.

In sum, a closer examination of the discursive arena can yield insights into such diverse social phenomena as repression backlash, the emergence of "strange bedfellow" coalitions, and the public toleration or even approval of mass killings, regardless of their violation of formerly shared social norms. Discourses can catalyze the acceptance of oppressive power relations or the emergence of projects of resistance that challenge the status quo. It is thus imperative to develop new methods to capture and analyze these discourses if we want to achieve a better understanding of the volatility and "eventfulness" (Della Porta, 2011) of contentious cycles.

In this book, I have suggested one potential way forward, in the shape of a multimethod approach that combines protest event analyses and discourse analyses. In this approach, described in detail in the Appendix, event catalogs function as heuristic tools to capture the "rhythm" of mobilization and to identify crucial turning points, whereas semantic networks provide the means to capture discursive shifts. The integration of discourse-theoretical considerations and event history approaches cannot explain why certain perceptions and interpretations of political reality spread and created political legitimacies (whereas others fail to do so). What it can do, however, is to shed some light on the ways in which social players construct their own discursive windows of opportunity for mobilization and alliance-building.

\section{Prospects for Resistance in Egypt}

Progressive activists, movements, and civil society associations are fighting an uphill battle in Egypt and, regrettably, this book provides no blueprint for 
more effective resistance. However, it does show that even when the physical parameters of the protest arena are unfavorable to social mobilization, there often remain discursive spaces in which to challenge the status quo. One promising path for sustaining resistance in the context of near-total authoritarian closure lies in the symbolic erosion of the images of those in power through the exposure of disjuncture in their professed discourses. In line with James Scott's (2000 [1987]) notion of "weapons of the weak," I have illustrated how, at several instances of Egypt's post-revolutionary history, social players with little if any resources at their disposal successfully challenged their counterparts through diligent symbolic labor.

As Lisa Wedeen (1999) noted, "regimes attempt to control and manipulate the symbolic world, just as they attempt to control material resources or to construct institutions for enforcement and punishment" (p. 30). In this regard, showing how they perform actions inconsistent with their claims represents minor, yet often powerful rebellious acts that can dislocate hegemonic perceptions of social reality and undermine the legitimacy of a regime. One might expect that authorities would adapt to these discursive attacks by modifying their narrative to incorporate or co-opt pressure, in the same way as they modify their repressive repertoire in response to protests (see Della Porta \& Tarrow, 2012). However, this is easier said than done and such attempts often prove to be a real test for those in power: the discursive strategies that "work well" in generating support - which is why autocrats rely on them - are usually hard to abandon. They rely on clear-cut differences between what is right and wrong, what ought to be done, and who ought to be fought against. These categorizations cannot be changed easily without causing the entire order to sway. While nationalist or securitizing rhetoric may seem abstract, the consequences of making it the imperative for political action are thus substantial.

In this sense, the cases discussed in this book say something about the long-term prospects of Al-Sisi's autocratic rule in Egypt. They caution against overestimating the ability to govern the country by force and to draw legitimacy exclusively from a discourse centred on nationalism and the government's provision of security against domestic and foreign threats. While securitizing, nationalist discourses may work in the short-term to shore up regimes, in the long term, they must be sustained by real policies that positively affect their audience. This audience - in this case, the Egyptian public - continually evaluates their congruency, punishes the betrayal of proclaimed goals with dissent, and rewards congruence with loyalty. In the end, this balances the power of nationalism, because the emotional component that makes it effective, can also become its weak spot. 
As Khaled Abdalla (2016) stated, "scale the conceptual frameworks embedded in those narratives into buildings, institutions, laws, cultural norms, and suddenly the burden of a simple story can become overwhelming" (p. $36 \mathrm{f}$.)

Accordingly, the Tiran and Sanafir events represented just the first in a series of crises that opened windows for contestation by rendering visible the disparities between the Al-Sisi administration's professed values, and its actual conduct. The most significant of these mobilizations took place in September 2019, when across Egypt's provinces thousands of Egyptians took to the streets to protest state corruption and to demand Abdel Fattah el-Sisi's departure. What connected these protests with the Popular Campaign to Protect the Land (PCPL) was their trigger, the video messages of a former defense contractor that revealed government misconduct. From his exile in Spain, in the fall of 2019, the 45-year-old actor Mohamed Ali went public with details of the corrupt practices by which state contracts were awarded to military companies and private subcontractors owned by army generals. In a series of very deliberately crafted videos, Ali recounted his experience as a defense contractor - including with members of Al-Sisi's family and inner circle.

Notably, these anecdotes portrayed Al-Sisi's failure as a leader not as a result of poor choices but more generally as "a fundamental failure to appropriately prioritize the wellbeing of the people over himself" (Khamis \& Fowler, 2020, p. 40), thus tapping into the very narratives established by the PCPL to frame its nationalist resistance three years earlier. Like the PCPL, Ali used his media celebrity to call on Egyptians to take to the streets, claiming that the army and the police would stand with the people and that Al-Sisi's days in office were numbered. People heeded his call and took to the streets between September 20 and 27, 2019, in what were the largest demonstrations since the Egypt is not for sale!-campaign.

In the end, there was no show of solidarity on the part of the military, unlike Ali had promised. While the protests caught the authorities by surprise, the regime's reaction to them followed an established authoritarian playbook: telecommunications were disrupted, websites censored, and protesters arrested on sight or from their homes. In the northern industrial city of Suez, where the spark of the January 25-revolution was ignited, protesters battled the police for two days without any intervention by the armed forces. On the contrary, repression reached a new level when security forces resorted to kidnapping known dissidents and their lawyers, including some who had not even participated in the demonstrations. By September 27, 2019, the Ministry of Interior had deployed thousands of police and plainclothes officers to all major squares and rounded up over 4,00o protesters. 
Notwithstanding, the anti-corruption demonstrations were significant due to the discursive rifts they caused and the affective dynamics they triggered. Corruption is common knowledge among Egyptians. But for the public, it was still a different thing to learn that Al-Sisi's entourage had squandered billions of Egyptian pounds on luxurious palaces and dubious mega projects - especially in times of austerity measures when presidential statements regularly stressed the country's poverty. Like the PCPL a few years earlier, activists were able to capitalize on these inconsistencies, in a way that widened the horizon of possibility for contentious action and that reshaped the arena of protest. In light of this episode, it is far from certain that Al-Sisi will become Egypt's new "president-for-life" (R. Owen, 2012). A constitutional referendum may have extended the president's maximum term length until 2030. But several sensitive issues loom on the horizon that could test Al-Sisi's nationalist credentials well before then.

At Egypt's southern border, the popular uprising against President Omar Bashir and has placed Al-Sisi in a quandary between fears of a contagion effect and the need to accept the new realities and prevent soaring relations to its neighbor. Bashir's ouster and the repeated waves of mobilization against military rule in the years after demonstrated how civic aspirations for political and socio-economic participation have taken root in the region. They might resurface in Egypt as well, should its government fail to be more responsive to its citizens and their needs. In addition, Sudanese authorities in the past repeatedly called on their Egyptian counterparts to reopen negotiations to settle the dispute over the oil-rich Halaib and Shalatin Triangle, a disputed area of around $20,000 \mathrm{~km}^{2}$ at the Red Sea coast, in the borderlands between Egypt and Sudan. Since the deployment of military units in the mid-199os, Egypt has administered the area as part of the Red Sea province and categorically rejected any negotiation over its sovereignty (see Hassan, 2017). The border dispute remained unaddressed for several years. But as Sudan's transition proceeds, attempts to challenge Egypt on this front will likely resume. In March 2021, Al-Sisi's first official visit to Khartoum since Bashir's ouster foreshadowed a revival of the conflict. It was accompanied by countrywide demonstrations whose participants demanded a return of the disputed area to Sudan. In the following weeks, both military and civilian leaders in Khartoum commented on the contentious issue and called for a resolution of the border dispute. Should these efforts to reach a settlement over the Halaib triangle persist, this could spark new concerns among the Egyptian public over another cessation of national territories to a neighboring country - especially since Al-Sisi might be forced to make concessions in order to preserve Khartoum's strategic support in the Nile water conflict with Ethiopia. 
This conflict among the different riparian states of the Nile Basin has been going on for decades (see Cascão, 2011; Nicol \& Cascão, 2011). During most of this conflict period, Egypt sought cooperation rather than conflict, to maintain the lion's share of the river's waters that was awarded to Egypt through several colonial-era agreements. But in 2011, Ethiopia commenced the construction of the Grand Ethiopian Renaissance Dam (GERD) to harness the river's hydroelectric potential. This development dynamized the conflict, as it sparked fears in Cairo that the mega-dam in the headwaters of the Blue Nile would reduce the Nile's annual flow downstream (see Cascão \& Nicol, 2016; Lossow \& Roll, 2015). Today, Egypt is almost entirely dependent on the river, which supplies more than go percent of the country's water needs. Hence any reduction of this renewable water source is predicted to come with severe consequences downstream, above all, with a view to Egypt's agricultural production.

This scenario has been looming since the start of Al-Sisi's presidency, but it wasn't until recently that the completion of construction works on Africa's largest dam made the risk of changes in Egypt's water supplies imminent (F. H. Lawson, 2017). Though Al-Sisi has warned that any cutback of Egypt's water supplies would be treated as a direct threat to its national security, he has made little headway in deterring the project. Instead, Ethiopia implemented the first two phases of filling the GERD reservoir unilaterally in 2020 and 2021, without prior agreement from the southern riparians. The latter now fear that Ethiopia's rapid filling of the dam and its use of the Nile water for irrigation, paired with increased loss of water to condensation from the newly created reservoir, could cause a devastating water deficit downstream. Freshwater supplies could be reduced by more than one-third, if unmitigated - a deficit that would entail a considerable loss of Egypt's arable land (see Heggy et al., 2021). At the same time, Egypt's Ministry of Water Resources and Irrigation has yet to present any viable alternatives to confront the looming water crisis through effective resource management or innovative irrigation methods. Faced with this potentially destabilizing situation, the Egyptian government has shifted between bellicose rhetoric and attempts to resolve disputes over the operation of the dam through joint conflict mitigation mechanisms. But neither saber-rattling nor diplomatic protocol has worked, so far. In the face of Ethiopian intransigence, Al-Sisi's window for finding a resolution for the almost decade-long standoff appears to be closing.

To the west, the president faces an additional quandary in the Libyan civil war, between the need to project strength vis-à-vis his domestic audience, on the one hand, and the potential costs of further involvement in the conflict, 
on the other. This predicament was exacerbated by a Turkish military intervention on the side of the internationally recognized Government of National Accord in Tripoli, which turned the tides of war against Al-Sisi's ally General Haftar and tested President Al-Sisi's resolve. Al-Sisi's calls for a full retreat of all mercenaries and foreign fighters and his warnings that a permanent Turkish presence in Libya and would be viewed as a national threat (like in Addis Abeba) have thus far been ignored in Ankara. At the same time, Egypt's abilities to follow up on Al-Sisi's rhetoric through military action are questionable. The failure of Haftar's military campaign in 2020, instead, forced the Egyptian government to recalibrate its strategy and to withdraw its support for a confrontational policy in favor of diplomatic arrangements.

Finally, to the east, the Tiran and Sanafir islands controversy is likely to resurface again, should the Saudi crown prince move forward with his plans to build a metropolis and a 500 billion USD economic zone on the coast of the Red Sea - spanning across Jordanian and Egyptian territories, and including the recently conceded islands. It is uncertain whether the Al-Sisi administration will be able to keep a lid on all these highly symbolic issues. Should it fail to deliver on its promise to protect the nation's security and interest, this might once again drive Egyptians to the streets.

\section{References}

Abdalla, K. (2016). Changing frames and fault-lines. In M. Baker (Ed.), Translating dissent: Voices from and with the Egyptian Revolution (pp. 33-44). Routledge.

Abdelrahman, M. (2015). Egypt's long revolution: Protest movements and uprisings. Routledge. Alimi, E. Y., \& Meyer, D. S. (2011). Seasons of change: Arab Spring and political opportunities. Swiss Political Science Review, 17(4), 475-479. https://doi.org/10.1111/j.1662-6370.2011.02041.x

Amar, P. (2013). The security archipelago: Human-security states, sexuality politics, and the end of neoliberalism. Duke University Press.

Beissinger, M. R. (2002). Nationalist mobilization and the collapse of the Soviet state. Cambridge University Press.

Boudreau, V. (2005). Precarious regimes and matchup problems in the explanation of repressive policy. In C. Davenport, H. Johnston, \& C. Mueller (Eds.), Repression and mobilization (pp. 33-57). University of Minnesota Press.

Brand, L. A. (2014). Official stories: Politics and national narratives in Egypt and Algeria. Stanford University Press.

Cascão, A. E. (2011). Power relations, conflict, and cooperation in the eastern Nile river basin. In S. S. Elmusa (Ed.), The burden of resources: Oil and water in the Gulf Region and the Nile Basin (pp. 20-51). American University in Cairo Press.

Cascão, A. E., \& Nicol, A. (2016). GERD: New norms of cooperation in the Nile Basin? Water International, 41(4), 550-573. https://doi.org/10.1080/02508060.2016.1180763 
Chalcraft, J. (2014). Egypt's 25 January uprising, hegemonic contestation, and the explosion of the poor. In F. A. Gerges (Ed.), The new Middle East: Protest and revolution in the Arab World (pp. 155-179). Cambridge University Press.

Della Porta, D. (2011). Eventful protest, global conflicts: Social mechanisms in the reproduction of protest. In J. M. Jasper \& J. Goodwin (Eds.), Contention in context: Political opportunities and the emergence of protest (pp. 256-276). Stanford University Press.

Della Porta, D. (2017). Riding the wave: Protest cascades, and what we can learn from them. In D. Della Porta (Ed.), Global diffusion of protest: Riding the protest wave in the neoliberal crisis (pp. 9-30). Amsterdam University Press.

Della Porta, D. (2018). Protests as critical junctures: Some reflections towards a momentous approach to social movements. Social Movement Studies, 1-20. https://doi.org/10.1080/1474 2837.2018.1555458

Della Porta, D., \& Tarrow, S. (2012). Interactive diffusion: The coevolution of police and protest behavior with an application to transnational contention. Comparative Political Studies, 45(1), 119-152. https://doi.org/10.1177/0010414011425665

Duyvendak, J. W., \& Fillieule, O. (2015). Conclusion: Patterned fluidity: an interactionist perspective as a tool for exploring contentious politics. In J. W. Duyvendak \& J. M. Jasper (Eds.), Players and arenas: The interactive dynamics of protest (pp. 295-318). Amsterdam University Press. https://doi.org/10.2307/j.ctt16vj285.16

Duyvendak, J. W., \& Jasper, J. M. (Eds.). (2015). Breaking down the state: Protestors engaged. Amsterdam University Press.

El-Sharnouby, D. (2018). Youth subjectivity at a post-ideological turn: The 2011 revolution in Egypt and youth's political imaginary. A case study of the Bread and Freedom Party [Doctoral Dissertation at the Center of Middle Eastern and North African Politics]. Freie Universität Berlin.

Grimm, J. J. (2017, April 27). Convergent authoritarianisms in Egypt and Turkey [Carnegie Endowment for International Peace]. Sada. http://carnegieendowment.org/sada/68797

Halawa, H. (2021, October 11). Burning ambition: Egypt's return to regional leadership and how Europe should respond. European Council on Foreign Relations. https://ecfr.eu/publication/ burning-ambition-egypts-return-to-regional-leadership-and-how-europe-should-respond/

Hall, S. (1980). Cultural studies: Two paradigms. In Media, culture, and society: A critical reader (pp. 57-72). Sage.

Hamada, A. (2014). Understanding the military role in the Egyptian revolution: Comparing February 2011 and July 2013. In N. Belakhdar, I. Eickhof, A. el Khawaga, O. el Khawaga, C. Harders, \& S. Sandri (Eds.), Arab revolutions and beyond (pp. 29-40). Center for Middle Eastern and North African Politics.

Hamzawy, A., \& Dunne, M. (2017). Egypt's secular political parties: A struggle for identity and independence. Carnegie Endowment for International Peace. https://carnegieendowment. org/2017/03/31/egypt-s-secular-political-parties-struggle-for-identity-and-independencepub- 68482

Hassan, K. (2017, April 10). Land dispute continues to threaten Egypt-Sudan ties. Al-Monitor. http:// www.al-monitor.com/pulse/originals/2017/o4/sudan-expel-egyptians-halayeb-shalateentriangle.html

Heggy, E., Sharkawy, Z., \& Abotalib, A. Z. (2021). Egypt's water budget deficit and suggested mitigation policies for the Grand Ethiopian Renaissance Dam filling scenarios. Environmental Research Letters, 16(7), 1-17. https://doi.org/10.1088/1748-9326/acoac9

Herrera, L., \& El-Sharnouby, D. (2018, January 24). Alain Badiou on the Egyptian revolution, seven years later. OpenDemocracy. https://www.opendemocracy.net/north-africa-west-asia/ linda-herrera-dina-el-sharnouby/alain-badiou-on-egyptian-revolution-questions 
Jasper, J. M. (2015). Introduction: Playing the game. In J. M. Jasper \& J. W. Duyvendak (Eds.), Players and arenas: The interactive dynamics of protest (pp. 9-32). Amsterdam University Press. https://doi.org/10.2307/j.ctt16vj285.3

Jasper, J. M. (2018). The emotions of protest. The University of Chicago Press.

Jasper, J. M. (2019). Afterword: Comparative versus historical research. Social Movement Studies, 18(1), 130-136. https://doi.org/10.1080/14742837.2018.1540348

Jasper, J. M., \& Duyvendak, J. W. (Eds.). (2015). Players and arenas: The interactive dynamics of protest. Amsterdam University Press.

Jasper, J. M., \& Volpi, F. (2018). Introduction: Rethinking mobilization after the Arab uprisings. In F. Volpi \& J. M. Jasper (Eds.), Microfoundations of the Arab uprisings: Mapping interactions between regimes and protesters (pp. 11-40). Amsterdam University Press.

Khamis, S., \& Fowler, R. (2020). Arab resistance in the diaspora: Comparing the Saudi dissident and the Egyptian whistleblower.Journal of Arab \& Muslim Media Research, 13(1), 31-49. https:// doi.org/10.1386/jammr_oooo9_1

Khosrokhavar, F. (2018). Violence, social actors, and subjectivation in the Egyptian revolution. In F. Volpi \& J. M. Jasper (Eds.), Microfoundations of the Arab uprisings: Mapping interactions between regimes and protesters (pp. 159-182). Amsterdam University Press.

Kurzman, C. (2018). Conclusion: Unruly protest. In F. Volpi \& J. M. Jasper (Eds.), Microfoundations of the Arab uprisings: Mapping interactions between regimes and protesters (pp. 183-192). Amsterdam University Press.

Lawson, F. H. (2017). Egypt versus Ethiopia: The conflict over the Nile metastasizes. The International Spectator, 52(4), 129-144. https://doi.org/10.1080/03932729.2017.1333272

Lossow, T. von, \& Roll, S. (2015). Egypt's Nile water policy under Sisi: Security interests promote rapprochement with Ethiopia (SWP Comments C 11). Stiftung Wissenschaft und Politik. https://www.swp-berlin.org/en/publication/egypts-nile-water-policy/

Marfleet, P. (2016). Egypt: Contested revolution. Pluto Press.

McGarry, A., Davidson, R. J., Accornero, G., Jasper, J. M., \& Duyvendak, J. W. (2016). Players and arenas: Strategic interactionism in social movements studies. Social Movement Studies, 15(6), 634-642. https://doi.org/10.1080/14742837.2016.1199320

Melucci, A. (1996). Challenging codes: Collective action in the information age. Cambridge University Press.

Mogahed, D. (2013, July 25). Deep runs the divide [Carnegie Endowment for International Peace]. Sada. http://carnegieendowment.org/sada/index.cfm?fa $=$ show\&article $=52493 \&$ solr_hilite $=$

Nicol, A., \& Cascão, A. E. (2011). Against the flow - new power dynamics and upstream mobilisation in the Nile Basin. Review of African Political Economy, 38(128), 317-325.

Owen, R. (2012). Rise and fall of Arab presidents for life. Harvard University Press.

Polletta, F., \& Kretschmer, K. (2015). Movement factions: Players and processes. In J. M. Jasper \& J. W. Duyvendak (Eds.), Players and arenas: The interactive dynamics of protest (pp. 35-54). Amsterdam University Press. https://doi.org/10.2307/j.ctt16vj285.4

Pratt, N. (2015). After the 25 January Revolution: Democracy or authoritarianism in Egypt? In R. Abou-el-Fadl (Ed.), Revolutionary Egypt: Connecting domestic and international struggles. Routledge.

Rennick, S. A. (2015). The practice of politics and revolution: Egypt's revolutionary youth social movement [Doctoral Dissertation, Lund University]. https://lup.lub.lu.se/search/ws/ files/5309346/5274498.pdf

Schwedler, J. (2018). Routines and ruptures in anti-Israeli protests in Jordan. In F. Volpi \& J. M. Jasper (Eds.), Microfoundations of the Arab uprisings: Mapping interactions between regimes and protesters (pp. 67-88). Amsterdam University Press. 
Scott, J. C. (2000). Weapons of the weak: Everyday forms of peasant resistance (Reprint). Yale University Press.

Sika, N. M. (2017). Youth activism and contentious politics in Egypt: Dynamics of continuity and change. Cambridge University Press.

Siméant-Germanos, J. (2021). Conceptualizing contexts or contextualizing concepts? On some issues of the modeling of relational spaces in the study of collective action. Social Movement Studies, 2o(2), 139-154. https://doi.org/10.1080/14742837.2019.1629899

Vicari, S. (2015). The interpretative dimension of transformative events: Outrage management and collective action framing after the 2001 anti-G8 summit in Genoa. Social Movement Studies, 14(5), 596-614. https://doi.org/10.1080/14742837.2014.995076

Wagner-Pacifici, R. (2010). Theorizing the restlessness of events. American Journal of Sociology, 115(5), 1351-1386. https://doi.org/10.1086/651299

Wedeen, L. (1999). Ambiguities of domination: Politics, rhetoric, and symbols in contemporary Syria. University of Chicago Press.

Weipert-Fenner, I. (2021). Go local, go global: Studying popular protests in the MENA post-2011. Mediterranean Politics. 
